\title{
UHP as a mild and efficient catalyst for the synthesis of substituted imidazoles via multicomponent condensation strategy
}

\author{
Ali Maleki*, Zahra Alirezvani, Nakisa Ghamari \\ Department of Chemistry, Iran University of Science \& Technology, Tehran 16846-13114, Iran \\ E-mail:maleki@iust.ac.ir
}

\begin{abstract}
A simple, highly versatile and efficient synthesis of 2,4,5-trisubstituted imidazoles is achieved by three-component cyclocondensation of 1,2-dicarbonyl compounds, aldehydes and $\mathrm{NH}_{4} \mathrm{OAc}$, as ammonia source using urea/hydrogen peroxide (UHP) as a supported green catalyst in refluxing ethanol. The key advantages of this process are high yields, cost effectiveness of catalyst and easy workup.
\end{abstract}

Keywords: Imidazole, benzil, benzoin, urea, hydrogen peroxide.

\section{Introduction}

Multicomponent reactions (MCRs) allow the assembly of complex molecules in one-pot and show a facile execution, high atom-economy and high selectivity, as afford good yields and are fundamentally different from two-component and stepwise reactions in several aspects [1].

Imidazoles are five-membered ring heteroaromatic compound bearing two nitrogen atoms at 1 and 3 positions [2]. These types of compounds are known to display a broad range of 
pharmaceutical and industrial applications. Imidazole cores are present in many compounds with pronounced biologic activities such as angiotensin inhibitors [3], anti-inflammatory [4], glucagon antagonist [5], antiviral [6], antimicrobial [7], fungicidal [8], and high cytotoxicity, which have indicated them as new candidates in cancer therapy [9]. In recent years, alkylated imidazoliums are substantially used in ionic liquids [10] that have been given a new approach to environmentally-benign and green chemistry. The imidazole compounds were also used in photography as efficient photosensitive agents [11].

A number of methods have been developed for the synthesis of imidazoles. Generally 2,4,5-trisubstituted imidazoles are synthesized by three-component cyclocondensation of 1,2diketone or $\alpha$-hydroxyketone or $\alpha$-ketomonoxime with an aldehyde and ammonium acetate, which comprise the use of ionic liquids [12], refluxing in acetic acid [13], silica supported sulfuric acid [14], $\mathrm{InCl}_{3} \cdot 3 \mathrm{H}_{2} \mathrm{O}$ [15], ceric ammonium nitrate (CAN) [16], $\mathrm{NiCl}_{2} \cdot 6 \mathrm{H}_{2} \mathrm{O} / \mathrm{Al}_{2} \mathrm{O}_{3}$ [17] and microwave irradiation [18]. Many of the synthetic methods for imidazoles suffer from one or more disadvantages such as low yields, strict reaction conditions, long time period and expensive catalysts and difficult workup.

In continuation of our interest in the application of new catalysts in organic synthesis via MCRs [23], herein, an efficient and highly selective synthesis of highly substituted imidazoles 4 has been developed by the condensation of benzil $\mathbf{1}$ or benzoin $\mathbf{2}$ with various substituted aldehydes $\mathbf{3}$ and ammonium acetate using urea/hydrogen peroxide (UHP) as a supported green catalyst in refluxing ethanol for $2-5 \mathrm{~h}$ under mild reaction conditions and excellent yields (Scheme 1). For the first time, UHP is introduced in the synthesis of substituted imidazoles which has been performed as an inexpensive catalyst that can be easily separated and has excellent solubility in water and organic solvents. 


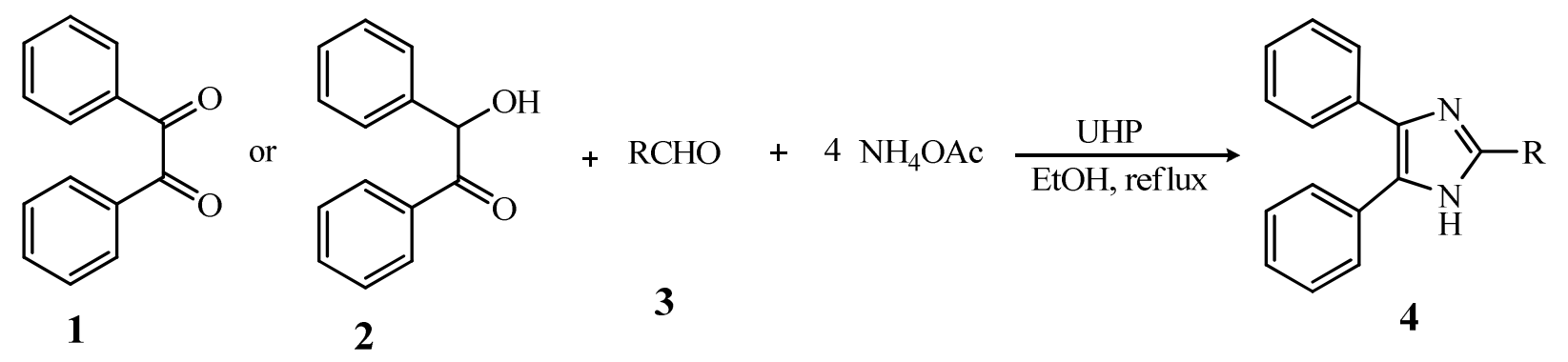

Scheme 1. Synthesis of 2,4,5-trisubstituted imidazoles by UHP catalyst.

\section{Experimental}

\section{Instruments and characterization}

All chemicals were purchased from Merck, Fluka and Sigma-Aldrich companies and were used without further purification. All reactions and the purity of imidazole derivaties were monitored by thin-layer chromatography (TLC) using aluminum plates coated with silica gel F254 plates (Merck) using ethyl acetate and $n$-hexane as eluents. The spots were detected either under UV light or by placing in an iodine chamber. Melting points were determined in open capillaries using an Electrothermal 9100 instrument.

General procedure for the synthesis of imidazoles

A mixture of benzil or benzoin $(1.0 \mathrm{mmol})$, an aldehyde $(1.0 \mathrm{mmol}), \mathrm{NH}_{4} \mathrm{OAc}(4.0 \mathrm{mmol})$ and UHP $(0.05 \mathrm{~g})$ was carried out in refluxing EtOH at $80{ }^{\circ} \mathrm{C}$. The progress of the reaction was monitored by TLC and after a period of $2-4 \mathrm{~h}$, the starting materials were consumed. After this time, the reaction was stopped and the crude product was isolated by filtration of the reaction mixture. Pure products were obtained via re-crystallization by EtOH. 


\section{Results and Discussion}

In a pilot experiment, a mixture of $1.0 \mathrm{mmol}$ of benzil, $1.0 \mathrm{mmol}$ of benzaldehyde, 4.0 mmol of ammonium acetate and UHP $(0.05 \mathrm{~g})$ in $4 \mathrm{~mL}$ of EtOH as solvent in a vial was stirred under refluxing conditions. The progress of the reaction was monitored by TLC. After completion of the reaction, the solid product were collected by a simple filtration and washed with acetone. In order to show the general applicability of the method a variety of imidazoles were synthesized using different aldehydes. Various halogens and electron withdrawing groups on the aldehydes were well tolerated and yields are almost quantitative in all cases (Table 1).

Table 1. UHP catalyzed three-component reaction for the synthesis of imidazole derivatives.<smiles>O=C(C(=O)c1ccccc1)c1ccccc1</smiles>

1

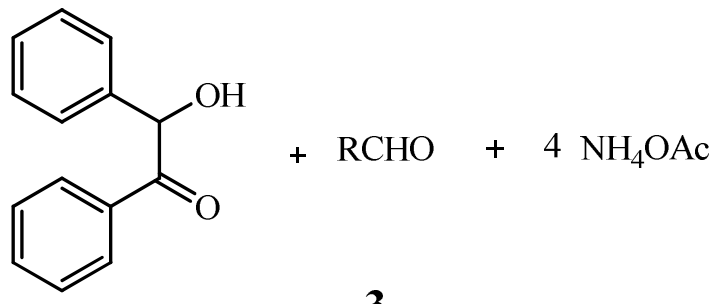

2<smiles>[R]c1nc(-c2ccccc2)c(-c2ccccc2)[nH]1</smiles>

4

\begin{tabular}{|c|c|c|c|c|c|c|}
\hline \multirow[b]{2}{*}{ Product } & \multirow[b]{2}{*}{$\mathrm{R}$} & \multirow[b]{2}{*}{ Time (h) } & \multicolumn{2}{|c|}{ Yield $^{\mathrm{a}}(\%)$} & \multicolumn{2}{|c|}{$\mathrm{Mp}(\mathrm{C})$} \\
\hline & & & $\begin{array}{c}\text { Benzil } \\
\mathbf{1}\end{array}$ & $\begin{array}{c}\text { Benzoin } \\
\mathbf{2}\end{array}$ & Found & Reported \\
\hline $4 a$ & $\mathrm{C}_{6} \mathrm{H}_{5}$ & 4 & 88 & 78 & $214-216$ & 216-217 [19] \\
\hline $4 b$ & $4-\mathrm{Cl}-\mathrm{C}_{6} \mathrm{H}_{4}$ & 2 & 95 & 90 & $265-267$ & $264-266$ [20] \\
\hline $4 c$ & $4-\mathrm{NO}_{2}-\mathrm{C}_{6} \mathrm{H}_{4}$ & 2 & 92 & 88 & $255-257$ & $255-257$ [21] \\
\hline $4 d$ & $2-\mathrm{Cl}-\mathrm{C}_{6} \mathrm{H}_{4}$ & 3 & 88 & 79 & $187-189$ & $187-188$ [22] \\
\hline
\end{tabular}

${ }^{\mathrm{a}}$ Isolated yield. 


\section{Conclusions}

In summary, a rapid, efficient, one-pot and highly selective synthesis of fully substituted imidazoles has been developed by the condensation reaction of benzil or benzoin with various substituted aldehydes and ammonium acetate in the presence of a catalytic amount of urea/hydrogen peroxide as a supported green catalyst in refluxing ethanol under mild reaction conditions in suitable time and excellent yields.

\section{Acknowledgements}

The authors gratefully acknowledge the partial support from the Research Council of the Iran University of Science and Technology.

\section{References}

[1] Dömling, A.; Wang, W.; Wang, K. Chem. Rev. 2012, 112, 3083.

[2] For reviews on the chemistry of imidazoles, see: Grimmett, M. R. In Comprehensive Heterocyclic Chemistry, Vol. 5; Katritzky, A. R.; Rees, C. W., eds.; Pergamon: Oxford, 1984; Grimmett, M. R. In Science of Synthesis, Vol. 12; Neier R., Ed.; Thieme: Stuttgart, 2002.

[3] Palkowitz, A. D.; Steinberg, M. I.; Thrasher, K. J.; Reel, J. K.; Hauser, K. L.; Zimmerman, K. M.; Wiest, S. A.; Whitesitt, C. A.; Simon, R. L.; Pfeifer, W.; Lifer, S. L.; Boyd, D. B.; Barnett, D. J.; Wilson, T. M.; Deeter, J. B.; Kakeuchi, K.; Riley, R. E.; Miller, W. D.; Marshall, W. S. J. Med. Chem. 1994, 37, 4508.

[4] Trujillo, J. I.; Kiefer, J. R.; Huang, W.; Thorarensen, A.; Xing, L.; Caspers, N. L.; Day, J. E.; Mathis, K. J.; Kretzmer, K. K.; Reitz, B. A.; Weinberg, R. A.; Stegeman, R. A.; 
Wrightstone, A.; Christine, L.; Compton, R.; Li, X. Bioorg. Med. Chem. Lett. 2009, 19, 908.

[5] Linda, L.; Chang, L. L.; Sidler, K. L.; Cascieri, M. A.; Laszlo, S.; Koch, G.; Li, B.; MacCoss, M.; Mantlo, N.; O’Keefe, S.; Pang, M.; Rolandoc, A.; Hagmanna, W. K. Bioorg. Med. Chem. Lett. 2001, 11, 2549.

[6] Sharma, D.; Narasimhan, B.; Kumar, P.; Judge, V.; Narang, R.; Clercq, E.; Balzarini, J. Eur. J. Med. Chem. 2009, 44, 2347.

[7] Kumar, S.; Boehm, J.; Lee, J. C. Nat. Rev. Drug Disc. 2003, 2, 717.

[8] Laufer, S.; Koch, P. Org. Biomol. Chem. 2008, 6, 437.

[9] King, A. J.; Patrick, D. R.; Batorsky R. S.; Ho, M. L.; Do, H. T.; Zhang, S. Y.; Kumar, R.; Rusnak, A. K.; Wilson, D. M.; Hugger, E.; Wang, L.; Karreth, F.; Lougheed, J. C.; Lee, J.; Chau, D.; Stout, T. J.; May, E. W.; Rominger, C. M.; Schaber, M. D.; Luo, L.; Lakdawala, A. S.; Adams, J. L.; Contractor, R. G.; Smalley, K. S. M.; Herlyn, M.; Morrissey, M. M.; Tuveson, D. A.; Huang, P. S. Cancer Res. 2006, 66, 11100.

[10] Wasserscheid, P.; Keim, W. Angew. Chem. Int. Ed. Eng. 2000, 39, 37872.

[11] Satoru, I. J. Pat. 01, 117, 867, May 10, 1989; Chem. Abstr. 1989, 111, 214482.

[12] Siddiqui, S. A.; Narkhede, U. C.; Palimkar, S. S.; Daniel, T.; Lahoti, R. J.; Srinivasan, K. V. Tetrahedron 2005, 61, 3539.

[13] (a) Wang, J.; Mason, R.; Derveer, D. V.; Feng, K.; Bu, X. R. J. Org. Chem. 2003, 68, 5415; (b) Sarshar, S.; Siev, D.; Mjalli, A. M. M. Tetrahedron Lett. 1996, 37, 835; (c) Gallagher, T. F.; Seibel, G. L.; Kassis, S.; Laydon, J. T.; Blumenthal, M. J.; Lee, J. C.; Lee, D.; Boehm, J. C.; Fier-Thompson, S. M.; Abt, J. W.; Soreson, M. E.; Smietana, J. M.; Hall, R. F.; Garigipati, R. S.; Bender, P. E.; Erhard, K. F.; Krog, A. J.; Hofmann, G. A.; 
Sheldrake, P. L.; McDonnell, P. C.; Kumar, S.; Young, P. R.; Adams, J. L. Bioorg. Med. Chem. 1997, 5, 49; (d) Steck, E. A.; Day, A. R. J. Am. Chem. Soc. 1943, 65, 452.

[14] Shaabani, A.; Rahmati, A. J. Mol. Catal. A: Chem. 2006, 249, 246.

[15] (a) Sharma, S. D.; Hazarika, P.; Konwar, D. Tetrahedron Lett. 2008, 49, 2216.

[16] Sangshetti, J. N.; Kokare, N. D.; Kothrkara, S. A.; Shinde, D. B. J. Chem. Sci. 2008, 120, 463.

[17] Heravi, M. M.; Bakhtiari, K.; Oskooie, H. A.; Taheri, S. J. Mol. Catal. A: Chem. 2007, $263,279$.

[18] (a) Bogevig, A.; Kumaragurubaran, N.; Juhl, K.; Zhuang, W.; Jorgensen, K. A. Angew. Chem., Int. Ed. 2002, 41, 1790; (b) Wolkenberg, S. E.; Wisnoski, D. D.; Leister, W. H.; Wang, Y.; Zhao, Z.; Lindsley, C. W. Org. Lett. 2004, 6, 1453; (c) Usyatinsky, A. Y.; Khmelnitsky, Y. L. Tetrahedron Lett. 2000, 41, 5031.

[19] Sivakumar, K.; Kathirvel, A.; Lalitha, A. Tetrahedron Lett. 2010, 51, 3018.

[20] Mohammadi, A.; Rouhi, H.; Keshvari, H.; Sepehr, Z.; Sandaroos, R. J. Chem. Sci. 2012, $124,717$.

[21] Kimura, M.; Iwagaki, H.; Tsunenaga, M.; Inoue, S. U.S. Pat. 2007, 112061.

[22] Sharma, S. D.; Hazarika, P.; Konwar, D. Tetrahedron Lett. 2008, 49, 2216.

[23] (a) Maleki, A. Tetrahedron 2012, 68, 7827; (b) Maleki, A. Tetrahedron Lett. 2013, 54, 2055. 